\title{
Адмиттанс гибридных органо-неорганических структур на основе пентацена в широком диапазоне температур
}

\author{
А.В. Войцеховский ${ }^{1,2)}$, С.Н. Несмелов ${ }^{1)}$, С.М. Дзядух ${ }^{1)}$ \\ ${ }^{1}$ Национальный исследовательский Томский государственный университет, \\ Томск, 634050, пр. Ленина, 36 \\ ${ }^{2}$ Сибирский физико-технический институт ТГУ, Томск, 634050, пл. Новособорная, 1 \\ тел:+7 (3822) 41-2772, факс:+7 (3822) 41-2772, эл.nочта: vav43@mail.tsu.ru
}

DOI 10.34077/RCSP2019-165

Интерес $к$ исследованиям электрофизических характеристик многослойных органонеорганических систем обусловлен возможностями совмещения приборов органической электроники (например, солнечных элементов, светодиодов, тонкопленочных транзисторов) с традиционными устройствами на основе неорганических полупроводников и диэлектриков [1]. Измерение адмиттанса МДП-структур на основе органических полупроводников при различных частотах и напряжениях обеспечивает получение важной информации о свойствах органических пленок и границ раздела между диэлектриками и органическими полупроводниками [2,3]. В данной работе в широком диапазоне условий экспериментально исследованы частотные, температурные и полевые зависимости адмиттанса МДП-структур на основе пентацена с различными диэлектрическими слоями $\left(\mathrm{SiO}_{2}\right.$ и $\left.\mathrm{SiO}_{2} / \mathrm{Ga}_{2} \mathrm{O}_{3}\right)$.

Установлено, что при достаточно высоких температурах (около 300 К) минимальные значения емкости на вольт-фарадных характеристиках (ВФХ) исследованных МДП-структур определяются не полным обеднением пленки пентацена, а образованием инверсионного слоя, время формирования которого составляет около 10 секунд. При охлаждении до $260 \mathrm{~K}$ (в случае $\mathrm{SiO}_{2} / \mathrm{Ga}_{2} \mathrm{O}_{3}$ ) или до $100 \mathrm{~K}$ (случай $\mathrm{SiO}_{2}$ ) инверсионный слой не успевает сформироваться [4]. При различных частотах и температурах определена концентрация дырок в пентацене. Измеренные частотные зависимости адмиттанса структур с диэлектриком $\mathrm{SiO}_{2}$ хорошо согласуются с результатами расчета. На зависимости приведенной проводимости от температуры обнаружены максимумы (рисунок), связанные с ловушками в объеме пентацена.

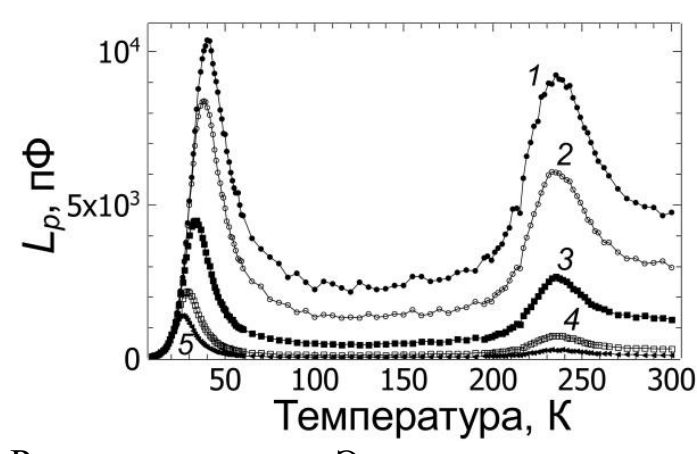

Рисунок. Экспериментальные зависимости проводимости $L_{p}$ структуры с диэлектриком $\mathrm{SiO}_{2} / \mathrm{Ga}_{2} \mathrm{O}_{3}$ от температуры, измеренные на частоте 100 кГц при различных напряжениях, В: кр. $1--20$, кр. $2--10$, кр. $3-0$, кр. $4-10$, кр. $5-20$

Исследования проведены при финансовой поддержке РФФИ и Администрации Томской области в рамках научного проекта р_a № 18-43-700005.

\section{Лumepamypa}

[1] P.Stallinga. Electrical characterization of organic electronic materials and devices. Chichester: John Wiley \& Sons, 2009. 316 p.

[2] M.Estrada, et al. // IEEE Trans. Electron Dev. 2013. V. 60, No. 6. P. 2057-2063.

[3] H.Hirwa, S.Pittner, V.Wagner // Org. Electron. 2015. V. 24. P. 303-314.

[4] В.А.Новиков и др. // Изв. вузов. Физика. 2019. Т. 62, вып. 1. С. 79-87. 